\title{
IMPROVING THE QUALITY CONDITION OF THE STRUCTURE OF WELDED JOINTS MADE OF ROTOR STEEL
}

\author{
V.V. Dmytryk ${ }^{1}$, V.Yu.Skulsky ${ }^{2}$, I.V. Kasyanenko ${ }^{1}$, O.V. Vavilov ${ }^{3}$, O.G. Kantor ${ }^{3}$ \\ ${ }^{1}$ National Technical University "Kharkiv Polytechnic Institute”, Kharkiv, Ukraine; \\ ${ }^{2}$ E.O. Paton Electric Welding Institute of the NAS of Ukraine, Kyiv, Ukraine; \\ ${ }^{3}$ JSC "UkrainianEnergyMachines", Kharkiv, Ukraine \\ E-mail: igorkasyanen@gmail.com
}

\begin{abstract}
The solution to the problem of increasing the reliability and service life of the welded joint of the rotor involved obtaining its original structure with improved quality characteristics. Obtaining was achieved by improving the technology of automatic welding. This improvement was based on the performing the welding process on the optimized parameters of the mode, which provided the appropriate temperature regime of the one-piece connection that is made. Thus, the welding heat provided the formation of the original structure with higher quality characteristics in comparison with a similar structure obtained by the normal mode of welding. It was found that austenitic grains in the structure of the heat affected zone of the welded joint, which is heated above $A_{\mathrm{C} 3}$, are smaller in size compared to similar grains in the structure of the standard technology. Accordingly, the new decay products of austenite in the area of heat affected zone, which is heated to the temperature range $A_{C 1}-A_{C 3}$, were sorbitol and troostite. In general, by obtaining a better structure allowed to increase the reliability and increase the service life of the rotor by $10 \ldots 15 \%$.
\end{abstract}

\section{INTRODUCTION}

The problem of increasing the reliability of NPP turbine rotors, in connection with the increase in power of power units is becoming increasingly important. Welded turbine rotors are made of high-quality steel 25X2NMFA (TU 108-995-81), which consists of $0.23 \ldots 0.27 \mathrm{C} ; \quad 0.17 \ldots 0.35 \mathrm{Si} ; \quad 0.40 \ldots 0.70 \mathrm{Mn}$; $1.80 \ldots 2.20 \mathrm{Cr} ; \quad 0.40 \ldots 0.60 \mathrm{Mo} ; \quad \mathrm{V} \leq 0.05 \quad$ (by calculation); $\quad 1.30 \ldots 1.60 \mathrm{Ni} ; \quad \mathrm{C} \leq 0.25 ; \quad \mathrm{S} \leq 0.015$; $\mathrm{P} \leq 0.015$. Steel $25 \mathrm{H} 2 \mathrm{NMFA}$ is used for production of forged preparations for welded rotors of turbines K-1000-60-1500 and their modifications (K-1000-601500-2, etc.). The structure of the specified steel represented the released lower bainite, Fig. 1.

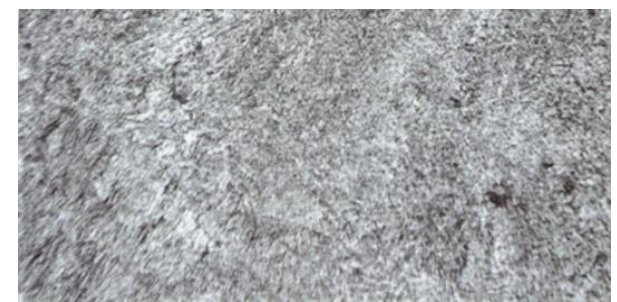

Fig. 1. The structure of the base metal of welded joints of steel $25 \mathrm{H} 2 \mathrm{NMFA}, \times 400$

The critical points of the induced steel $A_{C 1}-715^{\circ} \mathrm{C}$ and $A_{C 3}-785^{\circ} \mathrm{C}$. Welded joints of rotors according to regulatory requirements are subject to individual definition of mechanical properties with use of special methods of control. With regard to primary turbines for nuclear power plants, the level of regulatory requirements is higher.

Rotors made of induced steel (high and medium pressure) operate at a certain high temperature and are the most responsible component of turbines. Therefore, increasing the reliability and resource, according to the growing requirements, necessitates improving the performance of the welded rotor.

The performance characteristics of the metal of the welded joint of the rotor from the induced steel largely depend on the stability of him structural state. Therefore, improving the quality of the original structure of welded joints is an urgent problem. Note that for similar in chemical composition and structure of steels 15X2MFA and 15X2NMFA, which are used for the manufacture of reactor bodies WWER-440 and WWER-1000, this problem is also extremely important.

The aim of the work is to obtain a welded connection of the rotor from steel 25H2NMFA with improved quality of its initial structure.

\section{FORMULATION OF THE PROBLEM}

For research, a model of the welded joint of the rotor was specially made, which in size and shape corresponded to the actual welded connection of the rotor. This model was obtained from steel of the same chemical composition as the rotor itself, and also subjected to the same heat treatment. Welding of the prototype of the rotor was performed in an optimized mode [1], the parameters of which were determined by modeling the welding heat of the joint being manufactured [2]. Thus obtained welded joints with improved quality characteristics of its original structure.

The process of automatic welding involved pre- and associated heating of $300 \ldots 350^{\circ} \mathrm{C}$, as well as a certain cooling rate of the obtained connection. Specially developed equipment was used for welding, as well as welding wire SV-HN2GMY and flux AN-17m. Brewing of slit processing of edges, Fig. 2 was performed using an automatic electrode movement control system relative to the bottom and edges of the slit construction. The construction was filled with layers that were two rollers. 


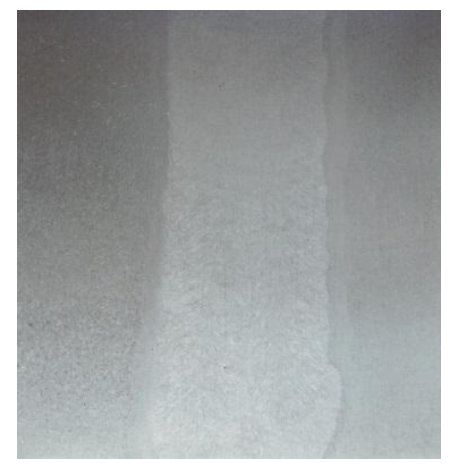

Fig. 2. Microstructure of the metal of the welded joint of the rotor made of steel $25 \mathrm{H} 2 \mathrm{NMF}, \times 11$

Metallographic studies were performed on sections of samples of the respective zones, cut along the cross section of the welded joint of the rotor, Fig. 3. The working surface of the samples was subjected to etching in a $20 \%$ aqueous solution of ammonium persulfate. Thus, the structure of the sites of HAZ, Fig. 4, where the structural transformations took place, acquired a significant contrast, which is important for its study. Optical microscopes MMO-1600 and MBS-7, as well as electron microscope JEOL-7100E were used to study the structural state, second phases and morphology of defects and non-metallic inclusions. Mechanical properties were determined according to regulatory requirements.

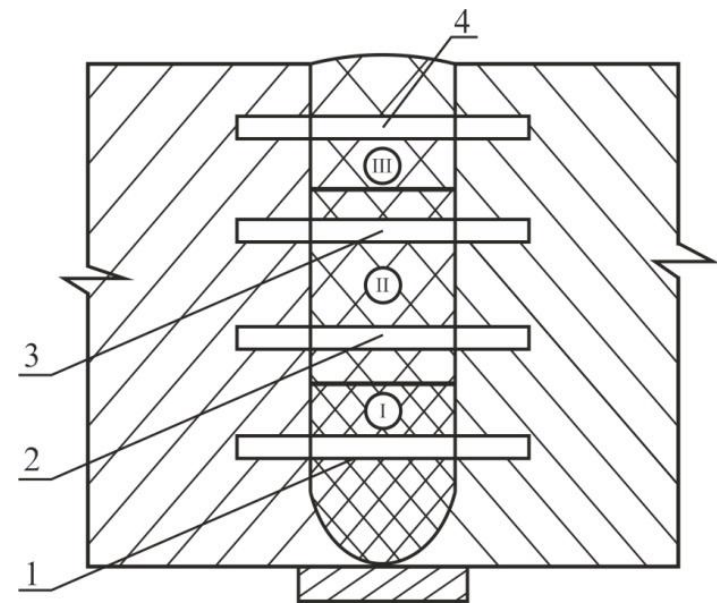

Fig. 3. Scheme of cutting samples (1-4) to study the structure of the welded joint. I-III-welding zones: I-lower; II-middle; III-upper

\section{RESULTS AND DISCUSSION}

Automatic welding of the standard rotor sample was performed at the modes recommended by the regulatory documentation [3,4]. At the same time, automatic welding of the prototype was performed on optimized modes $[1,2]$. In this way, the quality of the initial structural-phase state of the weld metal was improved. It is taken into account that the reliability of the welded joints of the rotors largely depends on their initial structural inhomogeneity, as well as the presence of structures that can be conditionally attributed to the rejection. For example: relatively large austenitic grains in the areas of fusion, overheating and normalization of HAZ of the welded joint; new decomposition products of austenite in the form of perlite in the area of incomplete recrystallization.

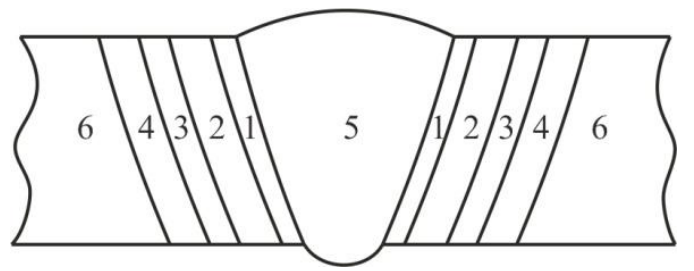

Fig. 4. The scheme of sites HAZ of welded connection of a rotor: 1 -fusion section; 2 - overheating;

3 -normalization; 4 -incomplete recrystallization;

5 -weld metal; 6 - the base metal, which has not undergone structural changes from welding heat

In the zone of thermal influence of welded joints, where the metal is heated to the temperature range $T_{L^{-}}$ $A_{C 3}$ (areas of fusion, overheating and normalization of HAZ) during welding at normal conditions can form large austenitic grains. Their value depends on the exposure in the above temperature range. In the works of I.A. Borisov [5], significant in level, made a significant contribution to solving this problem. Peculiarities of austenitic grains growth have been studied [5-8]. However, the task of preventing the formation of large austenitic grains in the metal structure of welded joints remained unsolved.

Austenitic grains in the metal of the welded joint have a significant impact on the formation of its original microstructure and significantly affect the mechanical properties and damage to the welded joint during its operation. Increasing the holding time of welded joints to $130 \mathrm{~h}$ when they are released $\left(600{ }^{\circ} \mathrm{C}\right)$ does not completely eliminate the ability of large austenitic grains to contribute to the damage of the metal of welded joints. That is why it is advisable to reduce the size of the austenitic grain in areas of the thermal zone, the metal of which during welding is heated to temperatures above $A_{C 3}$. The level of welding heating and the corresponding holding time in the areas of fusion, overheating and normalization of the zone of thermal influence of the welded joint differs significantly, which leads to a separate consideration of the conditions for the formation of their austenitic structure.

Aware of the previously performed studies [5-7], the above problem was solved by optimizing the parameters of the welding mode of the rotor joint being manufactured. The optimization of parameters was provided by modeling of welding heating of a rotor [2].

The simulation involved solving a thermal problem. Thus, the temperature regime of the welding process was established, which ensured the production of welded joints with high quality characteristics of their initial structure (Figs. 5, 6). By modeling, places were found in the weld metal and in the areas of HAZ, where reject structures can be formed, as well as structures that can be conditionally attributed to reject. For example: large austenitic grains in the areas of fusion. overheating and normalization of HAZ; new decay products of austenite in the form of globularized perlite in the area of incomplete recrystallization. It was found that these structures are mainly formed in the Central zone of the 
welded joint (see Fig. 3, samples 2, 3). It was found that the simulation of welding heating can prevent the appearance of structures, both rejecting and those that can be classified as rejecting. The dependence of the size of the austenitic grain on the level of temperature and the residence time of the metal in the areas of the zone of thermal influence in the temperature range of higher $A_{C 3}$ was revealed. Thus, the solution of the above problem with respect to welded joints made of 25H2NMFA steel was made possible by the introduction of automatic flux welding at optimized mode parameters.

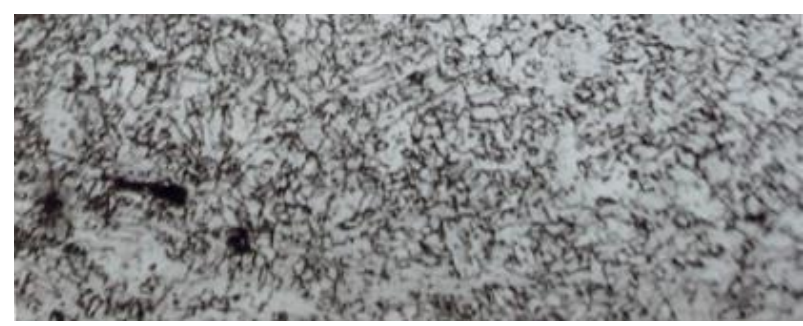

$a$

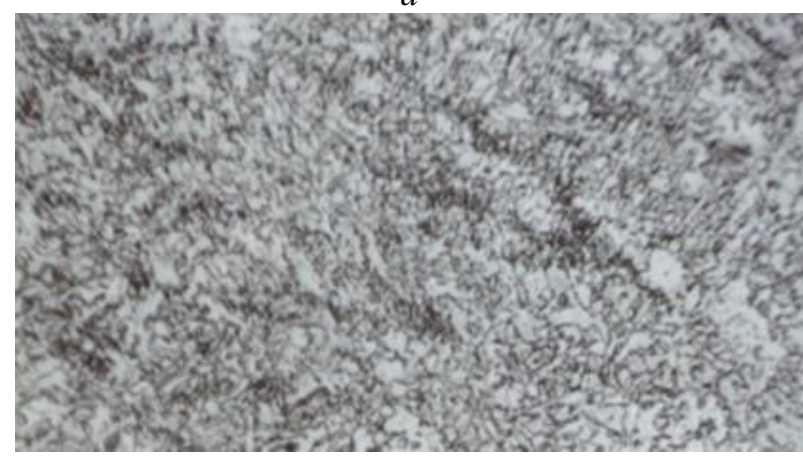

b

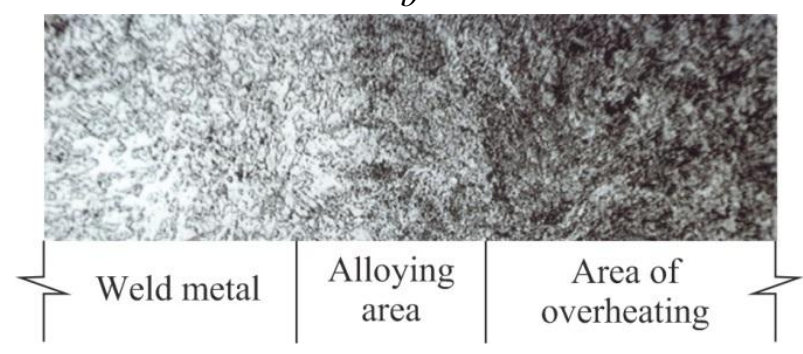

$c$

Fig. 5. The structure of the welded joint (see Fig. 3): $a$-weld metal, sample $1 ; b$-weld metal, sample 2 ; c-sample $3, \times 400$

Consider the areas of HAZ welded joint of the prototype made on the optimized parameters of the welding mode. The fusion section (size about $0.10 \ldots 0.15 \mathrm{~mm}$ ) is heated to the temperature range $T_{L}-T_{S}$. The grain size of austenite in this area in comparison with the grain size of the areas of overheating and normalization is greater and was 6-7 points ((GOST-5639-82), see Fig. 4). In the area of overheating, the width of which is about $1.3 \ldots 1.9 \mathrm{~mm}$ and is heated to the temperature range $T_{S}$ (upper limit) $1150{ }^{\circ} \mathrm{C}$ (close, lower limit), grain score $-7-8$. In the normalization section, which has a width of approximately $1.2 \ldots 1.7 \mathrm{~mm}$ and is heated to the temperature range of $1150{ }^{\circ} \mathrm{C}$ (near, upper limit) and $A_{3}-$ lower, the grain score was $8-9$, which is close to the initial value of steel grain. Thus, by using the optimized parameters of the automatic welding mode, a welded connection of the rotor with a smaller austenitic grain was obtained.

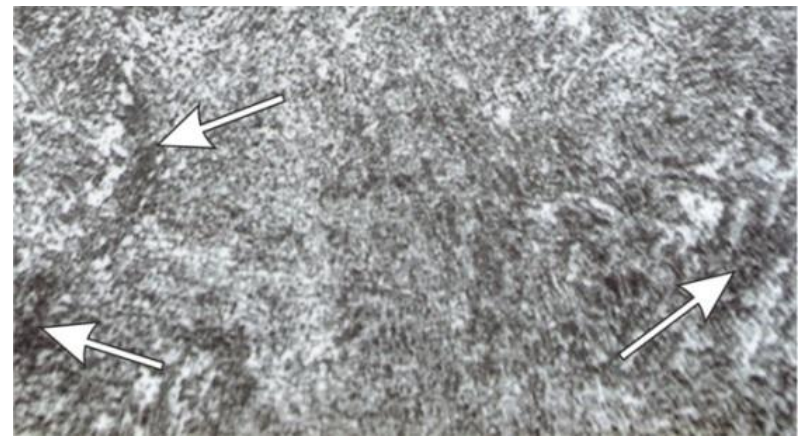

Fig. 6. The structure of the site of incomplete recrystallization of HAZ (see Fig. 3), sample 3, $\times 400$.

New decay products of austenite are indicated by arrows

In the area of incomplete recrystallization, the metal of which is heated during welding in the temperature range $A_{C 1}-A_{C 3}$, new decay products of austenite are formed in the form of troostite or sorbitol (see Fig. 6). In contrast to the welding in normal conditions, new decay products of austenite are formed in the form of perlite. The structure of perlite in the area of incomplete recrystallization of HAZ can be considered as defective. It is the presence of perlite that accelerates the damage of the metal in this area. Note that tempering also helps to improve the properties of welded joints.

In general, in the areas of HAZ, which are heated above $A_{C 3}$, thermal conditions ensure the formation of granular perlite. Tempering after welding promotes the further formation of bainite as granular. Gives it a round shape.

It was confirmed [7] that austenite in the metal of the fusion sites overheating and normalization of HAZ at a temperature of $380 \ldots 420^{\circ} \mathrm{C}$ does not completely decompose. This feature indicates the presence of $\alpha$-phase formation by martensitic kinetics. Residual austenite $(5 \ldots 7 \%)$ is converted into a ferritic carbide mixture during tempering $\left(600{ }^{\circ} \mathrm{C}\right.$, duration $\left.130 \mathrm{~h}\right)$. By optimizing the thermal conditions for obtaining welded joints, conditions are created for obtaining as little residual austenite as possible. This makes it possible to prevent the formation of martensite and significantly reduce the presence of residual austenite.

When welding using optimized mode parameters, welded joints were obtained, the hardness of which, in contrast to the hardness indicators [7] differs slightly (Figs. 7, 8).

Indicators of impact strength of welded joints obtained by advanced technology, compared with similar indicators increased by $10 . .15 \%$ and amounted to (Tables 1-4). 

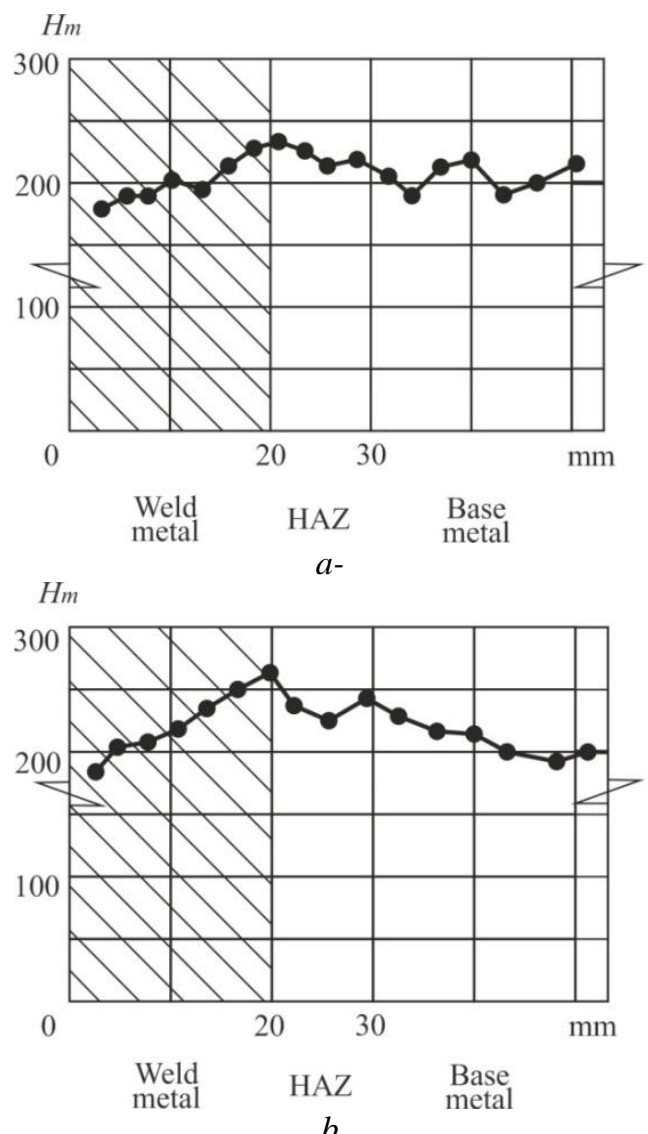

Fig. 7. Distribution of microhardness on cross section of welded connection (see Fig. 2): $a$-sample $1 ; b$-sample 2

Table 1

Impact strength of samples with $\mathrm{W}$-shaped notch on the weld metal

\begin{tabular}{|c|c|}
\hline Sample number & KCV index, J/cm ${ }^{2}$ \\
\hline Sample 1 & 159 \\
\hline Sample 2 & 142 \\
\hline Sample 3 & 145 \\
\hline Sample 4 & 147 \\
\hline
\end{tabular}

Table 2 Impact strength of samples with a V-shaped notch in the area of fusion of HAZ

\begin{tabular}{|c|c|}
\hline Sample number & KCV index, J/cm ${ }^{2}$ \\
\hline Sample 1 & 76 \\
\hline Sample 2 & 68 \\
\hline Sample 3 & 70 \\
\hline Sample 4 & 72 \\
\hline
\end{tabular}

Table 3

Impact strength of samples with a V-shaped notch in the area of overheating HAZ

\begin{tabular}{|c|c|}
\hline Sample number & KCV index, J/cm ${ }^{2}$ \\
\hline Sample 1 & 177 \\
\hline Sample 2 & 170 \\
\hline Sample 3 & 184 \\
\hline Sample 4 & 186 \\
\hline
\end{tabular}
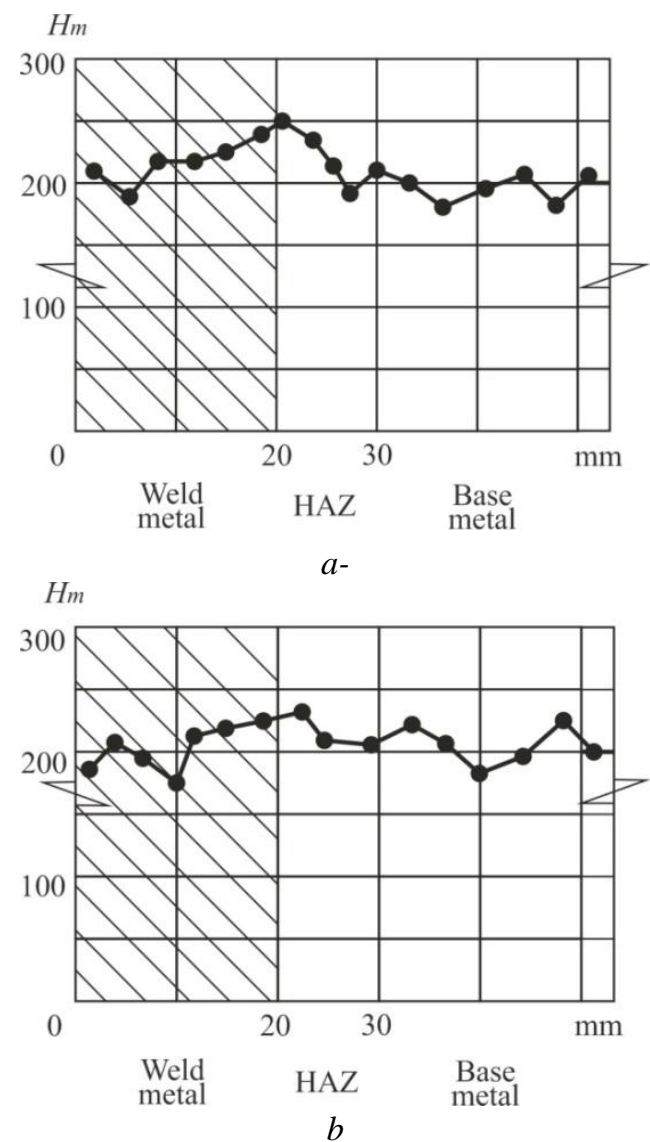

Fig. 8. Distribution of microhardness on cross section of welded connection (see Fig. 2): $a$-sample $3 ; b$-sample 4

Table 4

Impact strength of samples with $\mathrm{V}$-shaped notch in the area of incomplete recrystallization of HAZ

\begin{tabular}{|c|c|}
\hline Sample number & KCV index, J/cm \\
\hline Sample 1 & 77 \\
\hline Sample 2 & 65 \\
\hline Sample 3 & 67 \\
\hline Sample 4 & 72 \\
\hline
\end{tabular}

\section{CONCLUSIONS}

1. It is determined that the optimization of welding heating of the manufactured rotor, reduces the size of austenitic grains in the areas of fusion, overheating and normalization of HAZ, which improves the mechanical properties of welded joints. It was found that in the area of incomplete recrystallization of HAZ with the use of optimal welding heating, new decay products of austenite in the form of sorbitol or troostite are formed.

2. Optimization of thermal conditions for obtaining integral joints ensured the reduction of structural inhomogeneity in the areas of the thermal impact zone, which improves the mechanical properties of the metal of welded joints.

3. It is determined that in areas of fusion, overheating and normalization of HAZ welded joints made of steel 25H2NMFA forms granular bainite with a small amount of residual austenite (about 5...7\%), which during tempering turns into a ferrite-carbide mixture, which has no noticeable effect on the mechanical properties. 


\section{REFERENCES}

1. V.V. Dmytryk, V.I. Kalinichenko. Numerical solutions of problems of the theory of electric arc welding on the basis of Galerkin's scheme // Reports of the National Academy of Sciences of Ukraine. 2002, N 5, p. 101-108.

2. O.K. Morachkovsky, V.V. Dmytryk, O.P. Usatiy, B.P. Zaitsev, V.Yu. Skulsky, M.M. Grishin, Yu.G. Pashchenko, O.G. Cantor, O.W. Konovalenko. Creation of rotors of high-power turbines: Monograph. Kharkiv: FOP Panov A.M., 2018, 225 p.

3. Rules and norms in nuclear energy PNAEG-7030-91 "Unified methods of control of basic materials (semi-finished products), welded joints and surfacing equipment and pipelines of nuclear power plants", 1999, 37 p.

4. Equipment and pipelines of nuclear power plants. Welded joints and surfacing. Control rules. PNAEG-7-
010-89. Changes N 1 dated 01.09.2000. Gosatomnadzor of Russia, $97 \mathrm{p}$.

5. I.A. Borisov. Influence of overheating on the texture and grain of rotor steel // Metallurgy and heat treatment of metals. 2010, N 7, p. 3-9.

6. S.I. Herman, N.E. Levenberg, E.M. Netesa. The structure of the zone of thermal influence of welded joints in steel 24H2NMFA // Metallurgy and heat treatment of metals. 1977, N 12, p. 47-48.

7. A.C. Akritov, V.V. Altukhov, D.P. Antonets. Kinetics of austenite transformation into 14HG2MTR steel during welding thermal cycle // Welding production. 1986, N 10, p. 23-25.

8. I.A. Borisov. Influence of the duration of high tempering on the texture and grain of superheated rotor steel // Metallurgy and heat treatment of metals. 2013, N 3, p. 3-9.

Article received 01.12.2021

\title{
ПОВЫШЕНИЕ КАЧЕСТВЕННОГО СОСТОЯНИЯ СТРУКТУРЫ СВАРНЫХ СОЕДИНЕНИЙ ИЗ РОТОРНОЙ СТАЛИ
}

\author{
В.В. Дмитрик, В.Ю. Скульский, И.В. Касьяненко, А.В. Вавилов, А.Г. Кантор
}

Решение проблемы повышения надежности и срока наработки сварного соединения ротора предполагало получение его исходной структуры с улучшенными качественными характеристиками. Получение достигали путем усовершенствования технологии автоматической сварки. Такое усовершенствование основывалось на выполнении процесса сварки на оптимизированных параметрах режима, что обеспечило соответствующий температурный режим изготавливаемого неразъемного соединения. Таким образом, сварочный нагрев обеспечил формирование исходной структуры с более высокими качественными характеристиками по сравнению с аналогичной структурой, полученной по штатному режиму сварки. Установили, что аустенитные зерна в структуре зоны термического влияния сварного соединения, которая нагревается выше $A_{\mathrm{C} 3}$, меньшие по размерам, чем аналогичные зерна структуры штатной технологии. Соответственно новые продукты распада аустенита на участке зоны термического воздействия, нагреваемого в области температур $A_{C 1}-A_{C 3}$, представляли собой сорбит и троостит. В целом, в результате получения более качественной структуры удалось повысить надежность и увеличить ресурс наработки ротора на $10 \ldots 15 \%$.

\section{ПІДВИЩЕННЯ ЯКІСНОГО СТАНУ СТРУКТУРИ ЗВАРНИХ З'ЄДНАНЬ ІЗ РОТОРНОÏ СТАЛІ}

\section{В.В. Дмитрик, В.Ю. Скульський, І.В. Касьяненко, О.В .Вавілов, О.Г. Кантор}

Вирішення проблеми підвищення надійності і терміну напрацювання зварного з'єднання ротора передбачало отримання його вихідної структури з покращеними якісними характеристиками. Отримання досягали шляхом удосконалення технології автоматичного зварювання. Таке удосконалення грунтувалося на виконанні процесу зварювання на оптимізованих параметрах режиму, що забезпечило відповідний температурний режим нероз'ємного з'єднання, яке виготовляється. Таким чином, зварювальне нагрівання забезпечило формування вихідної структури з більш високими якісними характеристиками в порівнянні 3 аналогічною структурою, отриманою за штатним режимом зварювання. Встановили, що аустенітні зерна в структурі зони термічного впливу зварного з'єднання, яка нагрівається вище $A_{\mathrm{C} 3}$, є меншими за розмірами в порівнянні 3 аналогічними зернами структури штатної технології. Відповідно нові продукти розпаду аустеніту на ділянці зони термічного впливу, що нагрівається в області температур $A_{C 1}-A_{C 3}$, являли собою сорбіт і троостит. Загалом, шляхом отримання більш якісної структури вдалося підвищити надійність і збільшити ресурс напрацювання ротора на $10 \ldots 15 \%$. 